\title{
Synergistic actions of apomorphine and m-chlorophenylpiperazine on ejacu- lation, but not penile erection in rats
}

\author{
Akihiko Yonezawa ${ }^{1}$, Masaru Yoshizumi ${ }^{1}$, Shin-nosuke Ise $^{1}$, Chizuko Watanabe ${ }^{1}$, Hirokazu Mizoguchi ${ }^{1}$, Katsuo \\ Furukawa $^{2}$, Hiromichi Tsuru ${ }^{2}$, Yukio Kimura ${ }^{3}$, Masahito Kawatani ${ }^{4}$ and Shinobu Sakurada ${ }^{1}$ \\ ${ }^{1}$ Department of Physiology and Anatomy, Tohoku Pharmaceutical University, Sendai, Japan; ${ }^{2}$ Department of Pharmacology, Toho Uni- \\ versity School of Medicine, Tokyo, Japan; ${ }^{3}$ Towada Urology Hospital, Towada, Japan; and ${ }^{4}$ Department of Neurophysiology, Akita \\ University School of Medicine, Akita, Japan
}

(Received 24 December 2008; and accepted 8 January 2009)

\begin{abstract}
It has been suggested that dopamine (DA) and serotonin (5-HT) and their receptors, particularly $\mathrm{D}_{2}$-like and 5-HT $\mathrm{H}_{2 \mathrm{C}}$ receptors, may play a significant role in the control of male sexual function. The purpose of this study was to investigate whether the combination of a dopamine receptor agonist apomorphine and a 5- $\mathrm{HT}_{2}$ receptor agonist $\mathrm{m}-\mathrm{CPP}$ would potentiate penile erection and ejaculation in male rats. Systemic administration of either apomorphine $(0.01-0.1 \mathrm{mg} / \mathrm{kg}$, s.c.) or $\mathrm{m}$-CPP (0.01-0.3 mg/kg, i.p.) dose-dependently elicited penile erections, but did not induce ejaculation. When combined, there was a drastic increase in both the incidence of ejaculation and the amount of ejaculated seminal materials, while the proerectile effect induced by each drug was not potentiated. The proejaculatory effect induced by the combination of apomorphine $(0.1 \mathrm{mg} / \mathrm{kg}$, s.c. $)$ and $\mathrm{m}$-CPP $(0.3 \mathrm{mg} / \mathrm{kg}$, i.p. $)$ was completely blocked by pretreatment with the $\mathrm{D}_{2}$-like receptor antagonists haloperidol and sulpiride, but not by the $\mathrm{D}_{1}$-like receptor antagonist $\mathrm{SCH}-23390$. The synergistic action for ejaculation was also blocked by domperidone, the $\mathrm{D}_{2}$-like receptor antagonist that dose not cross the blood-brain barrier. The rats pretreated with the $5-\mathrm{HT}_{2 \mathrm{C}}$ receptor antagonist SB242084 did not show the synergistic action by the combination of apomorphine and $\mathrm{m}-\mathrm{CPP}$, whereas the rats pretreated with the $5-\mathrm{HT}_{2 \mathrm{~A}}$ receptor antagonist ketanserin and the $5-\mathrm{HT}_{2 \mathrm{~B}}$ receptor antagonist SB204741 showed the combination-induced synergistic action. These results suggest that the combination of a small dose of apomorphine and m-CPP potently and selectively facilitates the ejaculatory response through the activation of $\mathrm{D}_{2}$-like and 5- $\mathrm{HT}_{2 \mathrm{C}}$ receptors, respectively. The $\mathrm{D}_{2}$-like receptors involved in the synergistic action may be, at least in part, located in the peripheral sites.
\end{abstract}

Ejaculation is defined as a complex physiological process that results in the expulsion of the seminal fluid from the urethral meatus $(19,22)$. This process consists of three distinct phenomena: seminal emission (secretion of the mixed fluids composing semen

Address correspondence to: Akihiko Yonezawa, Ph.D., Department of Physiology and Anatomy, Tohoku Pharmaceutical University, 4-4-1 Komatsushima, Aoba-ku, Sendai 981-8558, Japan

Tel: +81-22-727-0125, Fax: +81-22-727-0125

E-mail: yonezawa@tohoku-pharm.ac.jp into the posterior urethra), ejaculation (expulsion of semen from the posterior urethra to the outside), and bladder neck closure. These events occur reflexively, and require coordination of autonomic and somatic nervous systems $(7,9,16)$ in order to achieve effective delivery of semen. A variety of neurotransmitters distributed in supraspinal and spinal sites are important for the controling ejaculation. Among the several neurotransmitters, it has been suggested that the dopaminergic and serotonergic systems have both excitatory and inhibitory influences on penile erection and ejaculation at the supraspinal level (10, 
14). Previous studies in our laboratory have revealed that systemic administration of the serotonin (5-HT)releasing agents such as $p$-chloroamphetamine (PCA) and fenfluramine can induce ejaculation in conscious and anesthetized rats $(31,32)$. Pretreatment with the 5-HT synthesis inhibitor $p$-chlorophenylalanine or $5-\mathrm{HT}_{1 / 2}$ and $5-\mathrm{HT}_{2}$ receptor antagonists (methysergide, ritanserin and ketanserin) significantly abolished the ejaculatory response induced by PCA or fenfluramine $(26,32,33)$. In addition, it has been shown that $5-\mathrm{HT}_{2}$ receptor agonist 5-methoxydimethyltryptamine facilitates ex copula seminal emission and ejaculation $(20,27,28) .5-\mathrm{HT}_{2}$ receptors can be divided into three subtypes: $5-\mathrm{HT}_{2 \mathrm{~A}}$, $5-\mathrm{HT}_{2 \mathrm{~B}}$ and $5-\mathrm{HT}_{2 \mathrm{C}}$ receptors (11). It has been shown that systemic administration of m-chlorophenylpiperazine (m-CPP), a 5- $\mathrm{HT}_{2}$ receptor agonist, produces ex copula responses such as penile erection in rats $(1,3)$. Furthermore, it has been recently reported that $\mathrm{m}$-CPP possesses the ability to induce ejaculation as well as penile erection in rats (34), and that these responses are primarily associated with the activation of $5-\mathrm{HT}_{2 \mathrm{C}}$ receptors. Support for this view comes from the recent finding that the selective 5- $\mathrm{HT}_{2 \mathrm{C}}$ receptor agonist Ro600175 can elicit a specific patterned burst response in the vas deferens nerve in rats (30), which is associated with the seminal emission and ejaculation phases of the ejaculatory process.

On the other hand, microinjection of apomorphine, a nonselective dopamine (DA) receptor agonist, into the medial preoptic area (MPOA) and paraventricular nucleus (PVN) facilitated seminal emission, and this effect was completely blocked by the $\mathrm{D}_{2}$ receptor antagonist raclopride $(13,25)$. Two separate DA receptor populations have been identified: $D_{1}$-like receptors $\left(D_{1}\right.$ and $\left.D_{5}\right)$ and $D_{2}$-like receptors $\left(D_{2}, D_{3}\right.$ and $\left.D_{4}\right)$. The selective $D_{2}$ receptor agonist quinelorane administered both systematically and microinjected into the MPOA facilitated seminal emission (4). Recent studies have demonstrated that i.c.v. injection of quinelorane induced rhythmic bursts of bulbospongiosus muscle contractions that are responsible for the propulsion of semen from the prostatic urethra to the urethral meatus as well as its forceful expulsion (6). These results indicate the possibility that the proejaculatory effect of apomorphine is likely mediated at supraspinal levels, and the effect may be related to the activation of $\mathrm{D}_{2}$ receptors. Recently, Stafford et al. (30) reported that the combination of Ro600175 and the 5- $\mathrm{HT}_{1 \mathrm{~A}}$ receptor agonist 8-OH-DPAT synergistically elicits contraction of the vas deferens through the activation of sympathetic preganglionic neurons in the spinal cord. However, 8-OH-DPAT has been reported to increase dopaminergic transmission into the MPOA by activation of $\mathrm{D}_{2}$-like receptors $(6,18,21)$. Thus, DA or 5-HT may promote ejaculation via the interaction of the DA and 5-HT receptor subtypes.

The purpose of the present study was to investigate whether the combination of a DA receptor agonist apomorphine and a 5- $\mathrm{HT}_{2}$ receptor agonist $\mathrm{m}$-CPP would enhance the ejaculatory response in rats. Additionally, we have examined to clarify the role of DA and 5- $\mathrm{HT}_{2}$ receptor subtypes in the combination-induced response.

\section{MATERIALS AND METHODS}

Animals. Adult male Wistar-ST strain rats (Japan SLC, Hamamatsu, Japan), weighing 300-400 g (1014 weeks old), were used for the present study. They were housed in a two rat per wire-bottomed stainless-steel cage $(35 \times 42 \times 20 \mathrm{~cm})$. Lighting was controlled on a $12: 12 \mathrm{~h}$ light-dark cycle (lights on at $09: 00)$. Constant temperature $\left(22-24^{\circ} \mathrm{C}\right.$ and humidity $(50-60 \%)$ were maintained and food and water were available ad libitum. The experiments were carried out between $11: 00-17: 00 \mathrm{~h}$. Each rat was used only once except for the dose-response experiment (Fig. 2). All animal procedures were approved by the Ethics Committee of Animal Experiments, Tohoku Pharmaceutical University and were carried out in accordance with the NIH Guide for the Care and Use of Laboratory Animals.

Drugs and treatments. The following drugs were used: apomorphine hydrochloride hemihydrate, $\mathrm{R}(+)$-7-chloro-8-hydroxy-3-methyl-1-phenyl2,3,4,5-tetrahydro-1H-3-benzazepine hydrochloride (SCH-23390), haloperidol, (-)-sulpiride, domperidone, $\mathrm{N}$-(1-methyl-1H-5-indolyl)-N'-(3-methyl-5-isothiazolyl)urea (SB204741), 6-chloro-5-methyl-1-[[2-(2methylpyrid-3-yloxy)pyrid-5-yl]carbamoyl]indoline dihydrochloride (SB242084) (all were obtained from Sigma-RBI, St. Louis, MO), 1-(3-chlorophenyl) piperazine hydrochloride (m-CPP; Tocris Cookson, Ellisville, MO), and ketanserin tartrate (Research Biochemicals International, Natick, MA). Apomorphine was dissolved in $0.1 \%$ L-ascorbic acid solution and diluted with sterilized saline. m-CPP, SCH-23390, ketanserin and SB242084 were dissolved in sterilized saline. Haloperidol, (-)-sulpiride and SB204741 were suspended in $0.5 \%$ Tween $80 /$ saline solution. Apomorphine was injected subcutaneous (s.c.) and other drugs were injected intraperi- 
toneally (i.p.) in a volume of $1 \mathrm{~mL} / \mathrm{kg}$ body weight. $\mathrm{m}$-CPP was injected i.p. immediately after s.c. apomorphine. Dopamine receptor antagonists such as $\mathrm{SCH}-23390$, haloperidol, (-)-sulpiride and domperidone were injected $30 \mathrm{~min}$ before the combination of apomorphine and m-CPP. 5- $\mathrm{HT}_{2}$ receptor antagonists such as ketanserin, SB204741 and SB242084 were injected 20, 30 and $20 \mathrm{~min}$ before the combination of apomorphine and $\mathrm{m}-\mathrm{CPP}$, respectively.

Observation of penile erections, ejaculation and other behavior. Prior to the testing, rats were placed in individual transparent plastic cages $(35 \times 40 \times 18 \mathrm{~cm})$ for at least $30 \mathrm{~min}$ to adapt to the novel environment. A paper towel was laid in the observation cage to confirm the occurrence of ejaculation. Before the drug administration, the presence of seminal materials on the paper towel as well as that adhering to the shaft of the penis was checked in order to alleviate any effect of spontaneous seminal emission. If seminal materials were detected, the test was discontinued and restarted the next day. In the present study the incidence of ejaculation was determined $30 \mathrm{~min}$ after apomorphine and $\mathrm{m}$-CPP administration, or combination of both, by the presence of seminal materials on the paper towel as well as that adhering to the shaft of the penis. If the animal ejaculated, the coagulated seminal materials were placed on filter paper for $30 \mathrm{~min}$, and then weighed. A penile erection was defined as previously described $(3,17,34)$; repeated pelvic thrusts immediately followed by an upright position on the hind limbs, an emerging, engorged penis and licking of the penis. The number of penile erections and yawns, or the duration of self-grooming behavior was simultaneously observed following the combination of apomorphine and m-CPP using an eventrecorder (MATYS, model CIF-E12; Toyo Sangyo, Toyama).

Statistics. Data were expressed as the means \pm S.E.M. The statistical significance of differences between means was analyzed with a one-way analysis of variance (ANOVA) followed by either Dunnett's test or Newman-Keuls test. The difference between the incidence of penile erection and ejaculation was analyzed by the Fisher's exact probability test.

\section{RESULTS}

Effects of apomorphine and $m$-CPP alone, or combination of both, on penile erection and ejaculation in rats Systemic administration of either apomorphine
$(0.01-0.1 \mathrm{mg} / \mathrm{kg}$, s.c.) or $\mathrm{m}-\mathrm{CPP}(0.01-0.3 \mathrm{mg} / \mathrm{kg}$, i.p.) dose-dependently elicited penile erections in rats, but did not induce ejaculation (Table 1). There was a slight incidence of the ejaculatory response at $0.3 \mathrm{mg} / \mathrm{kg}$ dose of $\mathrm{m}-\mathrm{CPP}$, but no incidence at lower doses $(0.01-0.1 \mathrm{mg} / \mathrm{kg})$. However, the combination of apomorphine $(0.1 \mathrm{mg} / \mathrm{kg})$ and $\mathrm{m}-\mathrm{CPP}(0.3 \mathrm{mg} / \mathrm{kg})$ drastically induced ejaculation (Fig. 1A); all animals receiving both drugs had ejaculations with a large amount of seminal materials $(53.8 \pm 16.8 \mathrm{mg} / \mathrm{kg}$, $\mathrm{n}=8$ ). By contrast, the synergistic action on penile erections was not observed by the combination (Fig. 1B). None of the vehicle-injected rats had the ejaculatory response during the observation period.

\section{Dose-dependent effects}

As shown in Table 2, the combination of a fixed dose $(0.1 \mathrm{mg} / \mathrm{kg})$ of apomorphine and the small doses $(0.01-0.3 \mathrm{mg} / \mathrm{kg})$ of $\mathrm{m}$-CPP dose-dependently increased both the incidence of ejaculation and the weight of seminal materials in comparison with apomorphine alone. The proerectile effect of apomorphine was not potentiated by the lower doses of m-CPP (data not shown). Likewise, the combination of a fixed dose $(0.3 \mathrm{mg} / \mathrm{kg})$ of $\mathrm{m}-\mathrm{CPP}$ and the small doses $(0.01-0.1 \mathrm{mg} / \mathrm{kg}$, i.p.) of apomorphine dosedependently induced the ejaculatory response in rats. The proerectile effect of $\mathrm{m}$-CPP was not potentiated by the lower doses of apomorphine (data not shown). Since a marked proejaculatory effect was seen in rats injected with the combination of apomorphine $(0.1 \mathrm{mg} / \mathrm{kg})$ and $\mathrm{m}-\mathrm{CPP}(0.3 \mathrm{mg} / \mathrm{kg})$, the dose of both drugs was chosen for the subsequent studies.

\section{Effect on other behaviors}

Systemic administration of apomorphine $(0.1 \mathrm{mg} / \mathrm{kg}$, s.c.) and $\mathrm{m}$-CPP $(0.3 \mathrm{mg} / \mathrm{kg}$, i.p. $)$ induced yawning and self-grooming in rats, respectively. As shown in Fig. 2, in contrast to ejaculation, the combined treatment did not potentiate the apomorphine-induced yawning and the m-CPP-induced self-grooming, respectively.

Effect of DA receptor antagonists on the ejaculatory response induced by the combination of apomorphine and $m-C P P$

To determine the involvement of the DA receptor subtype(s) in the synergistic action for ejaculation, several DA receptor antagonists were used for this purpose. As shown in Fig. 3A, pretreatment with the $\mathrm{D}_{2}$-like receptor antagonists haloperidol $(0.1 \mathrm{mg} / \mathrm{kg}$, i.p.) and (-)-sulpiride $(25 \mathrm{mg} / \mathrm{kg}$, i.p.) completely 
Table 1 Effects of apomorphine and $m-C P P$ on ejaculation and penile erection in rats

\begin{tabular}{lccc}
\hline & Ejaculation & & Penile erection \\
\cline { 2 - 3 } Dose $(\mathrm{mg} / \mathrm{kg})$ & Incidence $(\%)$ & Incidence $(\%)$ \\
Apomorphine $(0.01)$ & 0 & 33.3 \\
Apomorphine $(0.03)$ & 0 & 50 \\
Apomorphine $(0.1)$ & 0 & 50 \\
VEH & 0 & $100^{*}$ \\
m-CPP $(0.01)$ & 0 & 25 \\
m-CPP $(0.1)$ & 0 & 25 \\
m-CPP $(0.3)$ & 12.5 & 62.5 \\
\hline
\end{tabular}

$* P<0.05, * * P<0.01$, compared with vehicle $(\mathrm{VEH})$

blocked the ejaculatory response induced by the combination of apomorphine $(0.1 \mathrm{mg} / \mathrm{kg}$, s.c. $)$ and $\mathrm{m}$-CPP $(0.3 \mathrm{mg} / \mathrm{kg}$, i.p.), whereas the response induced by the combination was not inhibited by the $\mathrm{D}_{1}$-like receptor antagonist $\mathrm{SCH}-23390$ (0.1 and $0.3 \mathrm{mg} / \mathrm{kg}$, i.p.). Furtheremore, the synergistic action to the combination of apomorphine and m-CPP was also dose-dependently inhibited by domperidone, a $\mathrm{D}_{2}$-like receptor antagonist that dose not cross the blood-brain barrier (Fig. 3A). In contrast, penile erection induced by the combination of apomorphine and $\mathrm{m}$-CPP was not blocked by pretreatment with SCH-23390, haloperidol, (-)-sulpiride $(25 \mathrm{mg} /$ $\mathrm{kg}$, i.p.) or domperidone (Fig. 3B). Penile erection induced by apomorphine $(0.1 \mathrm{mg} / \mathrm{kg}$, s.c. $)$ alone was significantly inhibited by haloperidol $(0.1 \mathrm{mg} / \mathrm{kg}$, i.p.), but not by domperidone $(3.0 \mathrm{mg} / \mathrm{kg}$, i.p.) (data not shown).

Effect of 5-HT, receptor antagonists on the ejaculatory response induced by the combination of apomorphine and $m$-CPP

To determine the involvement of the $5-\mathrm{HT}_{2}$ receptor subtype(s) in the synergistic action on ejaculation, several $5-\mathrm{HT}_{2}$ receptor antagonists were used for this purpose. As shown in Fig. 4A, pretreatment with the 5- $\mathrm{HT}_{2 \mathrm{C}}$ receptor antagonist SB242084 (0.03 and $0.1 \mathrm{mg} / \mathrm{kg}$, i.p.) dose-dependently blocked the ejaculatory response induced by the combination of apomorphine $(0.1 \mathrm{mg} / \mathrm{kg}$, s.c. $)$ and $\mathrm{m}-\mathrm{CPP}(0.3 \mathrm{mg} /$ $\mathrm{kg}$, i.p.), whereas the response induced by the combination was not inhibited by the $5-\mathrm{HT}_{2 \mathrm{~A}}$ receptor antagonist ketanserin $(0.03$ and $0.1 \mathrm{mg} / \mathrm{kg}$, i.p.) and the 5- $\mathrm{HT}_{2 \mathrm{~B}}$ receptor antagonist SB204741 (0.1 and $0.3 \mathrm{mg} / \mathrm{kg}$, i.p.). In contrast, penile erection induced by the combination of apomorphine and m-CPP was not blocked by pretreatment with ketanserin, SB204741, and SB242084 (Fig. 4B). Penile erection induced by $\mathrm{m}-\mathrm{CPP}(0.3 \mathrm{mg} / \mathrm{kg}$, i.p. $)$ alone was com-

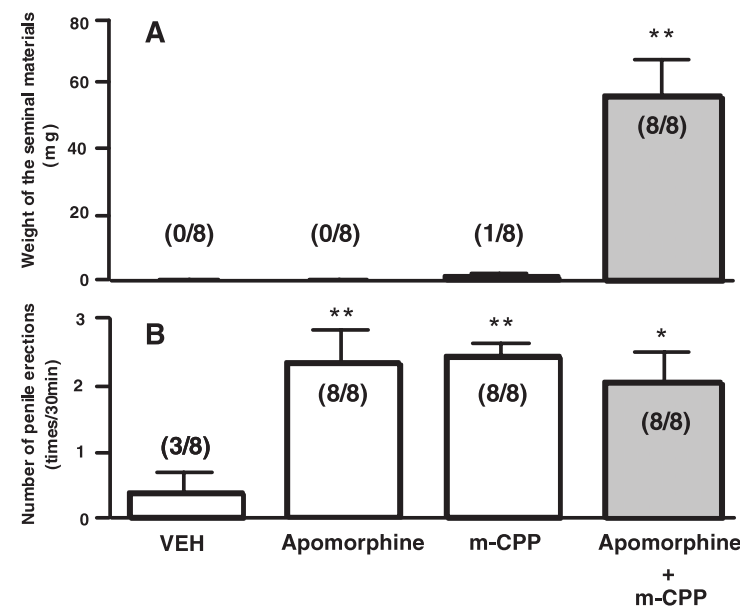

Fig. 1 Effect of apomorphine $(0.1 \mathrm{mg} / \mathrm{kg}$, s.c.), $\mathrm{m}-\mathrm{CPP}$ $(0.3 \mathrm{mg} / \mathrm{kg}$, i.p.) or combination of apomorphine $(0.1 \mathrm{mg} / \mathrm{kg})$ and $\mathrm{m}$-CPP $(0.3 \mathrm{mg} / \mathrm{kg})$ on ejaculation $(A)$ and penile erection $(B)$ in rats. $(A)$ and $(B)$ denote the weight of seminal materials and the number of penile erections during the observation period (for $30 \mathrm{~min}$ ), respectively. Each column represents the means \pm S.E.M. for 8 animals. The symbol indicates a significant difference $\left({ }^{\star} P<0.05,{ }^{*} P<0.01\right)$ from vehicle (VEH)-treated animals. The values expressed are the number of rats per group showing ejaculatory response.

pletely inhibited by SB242084 (0.1 mg/kg, i.p.), but not by ketanserin and SB204741 (data not shown).

\section{DISCUSSION}

The present study clearly demonstrated that the combination of a dopamine receptor agonist apomorphine and a $5-\mathrm{HT}_{2}$ receptor agonist $\mathrm{m}-\mathrm{CPP}$ potently facilitates the ejaculatory response in rats. In fact, when systemically co-administered with the sub-threshold doses, there was the drastic increase in both the incidence of ejaculation and the amount of ejaculated seminal materials (Fig. 1 and Table 2). We have recently reported that systemic administra- 
Table 2 Effects of combination of apomorphine and $m-C P P$ on ejaculation in rats

\begin{tabular}{ccc}
\hline & \multicolumn{2}{c}{ Ejaculation } \\
\cline { 2 - 3 } Dose $(\mathrm{mg} / \mathrm{kg})$ & $\begin{array}{c}\text { Proportion of } \\
\text { ejaculating animals }\end{array}$ & Weight $(\mathrm{mg})$ \\
\hline Apomorphine $(0.1)$ alone & $0 / 8$ & 0 \\
+ m-CPP $(0.01)$ & $3 / 8$ & $9.5 \pm 6.8$ \\
+ m-CPP $(0.1)$ & $5 / 8^{*}$ & $25.2 \pm 16.7$ \\
+ m-CPP $(0.3)$ & $8 / 8^{* *}$ & $51.8 \pm 16.8^{* *}$ \\
m-CPP (0.3) alone & $1 / 8$ & $0.7 \pm 0.4$ \\
+ apomorphine $(0.01)$ & $3 / 8$ & $3.3 \pm 2.3$ \\
+ apomorphine $(0.03)$ & $5 / 8$ & $26.7 \pm 14.1$ \\
+ apomorphine $(0.1)$ & $8 / 8^{* *}$ & $53.1 \pm 17.5^{* *}$ \\
\hline
\end{tabular}

$* P<0.05, * * P<0.01$, compared with apomorphine or $\mathrm{m}-\mathrm{CPP}$ alone

tion of a relatively high dose of $\mathrm{m}-\mathrm{CPP}$ produced ejaculation in rats; the $\mathrm{ED}_{50}$ value of $\mathrm{m}-\mathrm{CPP}$ for inducing ejaculation was $0.6 \mathrm{mg} / \mathrm{kg}(0.597-0.602 \mathrm{mg} /$ $\mathrm{kg}$, 95\% confidence intervals), while, in this study, the $\mathrm{ED}_{50}$ value of $\mathrm{m}$-CPP obtained by the combination with the fixed dose $(0.1 \mathrm{mg} / \mathrm{kg})$ of apomorphine was $0.023 \mathrm{mg} / \mathrm{kg}(0.017-0.032 \mathrm{mg} / \mathrm{kg}, 95 \%$ confidence intervals), indicating a drastic reduction in the threshold for ejaculation. Thus, the relative potency of the proejaculatory effect of m-CPP was 26-fold increase by the combination of apomorphine.

The combination of apomorphine and m-CPP may selectively potentiate the ejaculatory response in rats. In the present study, the proerectile effect of each compound was not enhanced by the combination (Fig. 1 and Table 1). We previously demonstrated that the dose-response curves for penile erection induced by $\mathrm{m}$-CPP are inverted U-shaped curves with the maximum effect at $0.6 \mathrm{mg} / \mathrm{kg}$ (number of penile erections $/ 30 \mathrm{~min} ; 4.3 \pm 0.8$ ) (34). Furthermore, neither the m-CPP-induced self-grooming nor the apomorphine-induced yawning was also enhanced by the combination of apomorphine and m-CPP (Fig. 2). These results indicate that the combination with a small dose of apomorphine and m-CPP may act synergistically to induce ejaculation without affecting other characterized behavioral response induced by each compound.

It has been shown that apomorphine exhibits a relatively high affinity for $\mathrm{D}_{1}$-like $\left(\mathrm{D}_{1}\right.$ and $\left.\mathrm{D}_{5}\right)$ and $\mathrm{D}_{2}$-like $\left(\mathrm{D}_{2}, \mathrm{D}_{3}\right.$ and $\left.\mathrm{D}_{4}\right)$ dopamine receptor subtypes ( $K \mathrm{i}$ values are $100,10,15,2.5$ and $50 \mathrm{nM}$ for human cloned $\mathrm{D}_{1}, \mathrm{D}_{2}, \mathrm{D}_{3}, \mathrm{D}_{4}$ and $\mathrm{D}_{5}$ receptors, respectively) (12), and elicits almost full agonistic activity at $\mathrm{D}_{2}$-like receptors. Also, $\mathrm{m}$-CPP has been shown to exhibit a relatively high affinity for $5-\mathrm{HT}_{2 \mathrm{~A}}$, $5-\mathrm{HT}_{2 \mathrm{~B}}$ and $5-\mathrm{HT}_{2 \mathrm{C}}$ receptor subtypes ( $\mathrm{Ki}$ values are 80,40 and $16 \mathrm{nM}$ for human cloned $5-\mathrm{HT}_{2 \mathrm{~A}}, 5-\mathrm{HT}_{2 \mathrm{~B}}$

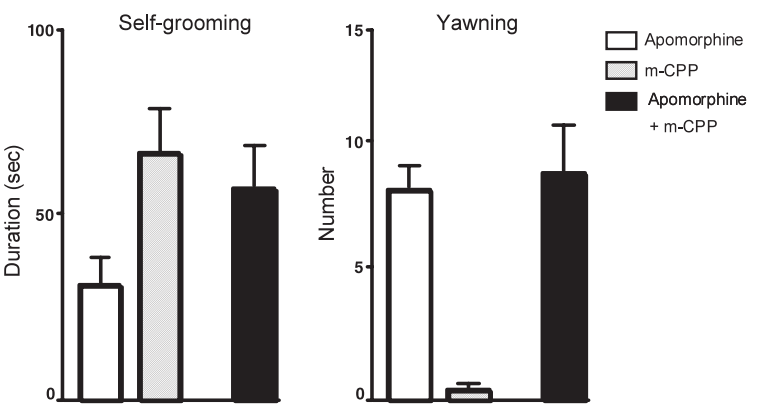

Fig. 2 Effect of apomorphine (0.1 mg/kg, s.c.), m-CPP $(0.3 \mathrm{mg} / \mathrm{kg}$, i.p.) or combination of apomorphine $(0.1 \mathrm{mg} / \mathrm{kg})$ and $\mathrm{m}$-CPP $(0.3 \mathrm{mg} / \mathrm{kg})$ on self-grooming and yawing in rats. Results of the duration of self-grooming and the number of yawing are shown as means \pm S.E.M. for 8 animals.

and $5-\mathrm{HT}_{2 \mathrm{C}}$ receptors, respectively) (17). The proerectile effects of apomorphine and $\mathrm{m}$-CPP have shown to be mediated by the activation of $\mathrm{D}_{2}$-like and $5-\mathrm{HT}_{2 \mathrm{C}}$ receptors, respectively $(12,17,23)$. The results obtained in the present study also indicate that activation of both $\mathrm{D}_{2}$-like receptor by apomorphine and $5-\mathrm{HT}_{2 \mathrm{C}}$ receptor by m-CPP may involve the synergistic action for inducing ejaculation induced by the combination of both compounds. This is evidenced by the findings that the synergistic action for the co-administered apomorphine and $\mathrm{m}$-CPP was completely abolished by pretreatment with the $\mathrm{D}_{2}$-like receptor antagonists (haloperidol and sulpilide), but not by the $\mathrm{D}_{1}$-like receptor antagonist (SCH-23390), while pretreatment with the selective $5-\mathrm{HT}_{2 \mathrm{C}}$ receptor antagonist (SB242084), but not the 5- $\mathrm{HT}_{2 \mathrm{~A}}$ and 5- $\mathrm{HT}_{2 \mathrm{~B}}$ receptor antagonists (ketanserin and SB204741), dose-dependently blocked the ejaculatory response induced by the combination. The lack of effects of these antagonists on the proerectile effect induced by the combination (Fig. 1), confirms the importance of the simultaneous activa- 


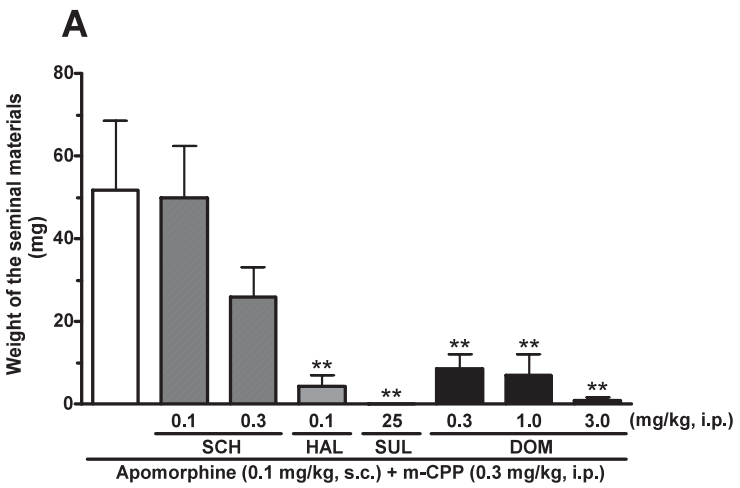

B

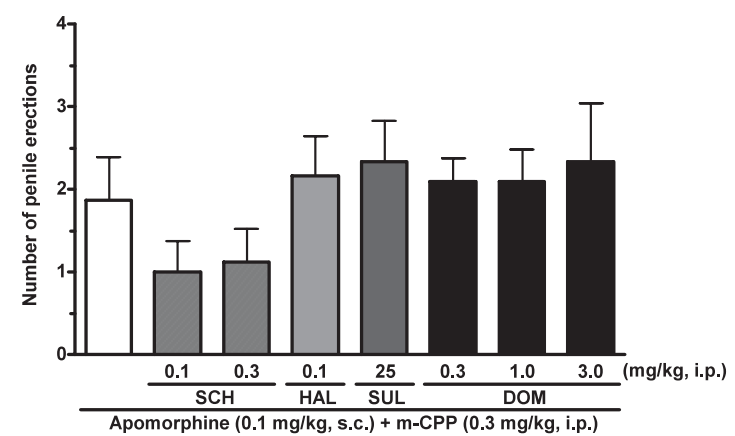

Fig. 3 Effect of DA receptor antagonists on the combination of apomorphine and $\mathrm{m}-\mathrm{CPP}$ induced ejaculation $(\mathrm{A})$ and penile erection $(B)$ in rats. $(\mathbf{A})$ and $(B)$ denote the weight of seminal materials and the number of penile erections, which were pretreated with the $D_{1}$-like and $D_{2}$-like receptor antagonists, respectively. Each column represents the means \pm S.E.M. for 8 animals. The symbol indicates a significant difference $\left({ }^{\star *} P<0.01\right)$ from vehicle $(\mathrm{VEH})$-treated animals. $\mathrm{SCH}=\mathrm{SCH}-23390, \mathrm{HAL}=$ haloperidol, $\mathrm{SUL}=$ sulpiride, $\mathrm{DOM}=$ domperidone.

tion of $\mathrm{D}_{2}$-like receptor by apomorphine and $5-\mathrm{HT}_{2 \mathrm{C}}$ receptor by $\mathrm{m}-\mathrm{CPP}$, respectively.

Several studies have shown that systemic and intracerebral (e.g., MPOA and PVN) administration of apomorphine can facilitate seminal emissions in rats, and this effect was blocked by the $\mathrm{D}_{2}$-like receptor antagonist $(4,13)$. Furthermore, systemic administration of apomorphine in anaesthetized rats has been shown to evoke the supraspinal-mediated bursting pattern response in the sympathetic vas deferens nerve that corresponds to ejaculation (29). These results suggest the possibility that the proejaculatory effect of apomorphine results in the activation of $\mathrm{D}_{2}$-like receptor at supraspinal level as with its proerectile effect (4). However, the result obtained in the present study demonstrates that $\mathrm{D}_{2}$ like receptor which mediated the synergistic action induced by the combination of apomorphine and

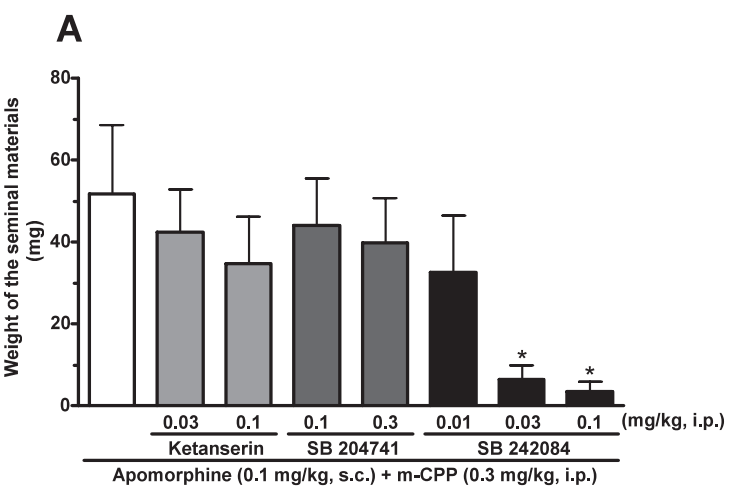

B

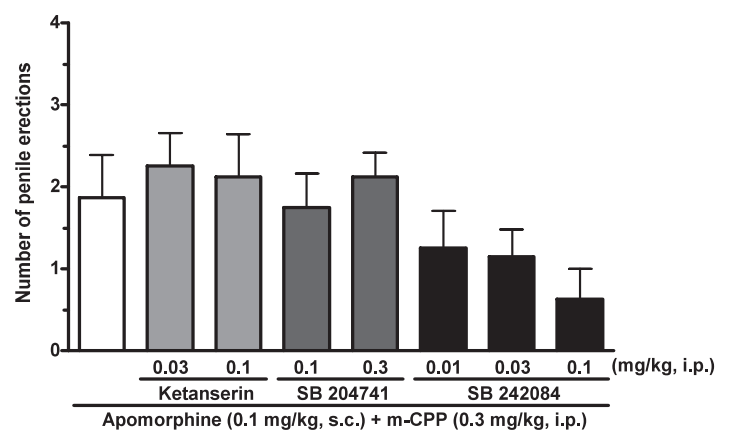

Fig. 4 Effect of $5-\mathrm{HT}_{2}$ receptor antagonists on the combination of apomorphine and $\mathrm{m}$-CPP induced ejaculation (A) and penile erection $(B)$ in rats. $(A)$ and $(B)$ denote the weight of seminal materials and the number of penile erections, which were pretreated with the $5-\mathrm{HT}_{2 \mathrm{~A}}, 5-\mathrm{HT}_{2 \mathrm{~B}}$ and $5-\mathrm{HT}_{2 \mathrm{C}}$ receptor antagonists, respectively. Each column represents the means \pm S.E.M. for 8 animals. The symbol indicates a significant difference $\left({ }^{*} P<0.05\right)$ from vehicle (VEH)-treated animals.

$\mathrm{m}$-CPP may be located in the peripheral sites rather than the supraspinal level. Thus, the proejaculatory effect of the co-administered apomorphine and $\mathrm{m}-\mathrm{CPP}$ was dose-dependently blocked by pretreatment with domperidone $(0.3-3.0 \mathrm{mg} / \mathrm{kg})$, a $\mathrm{D}_{2}$-like receptor antagonist that does not cross the bloodbrain barrier (2). As shown here and in previous studies $(8,24)$, the doses of domperidone used did not affect the erectile activity induced by apomorphine alone (i.e., central $\mathrm{D}_{2}$-like receptors-mediated response) (2) or the combination of apomorphine and $\mathrm{m}$-CPP, suggesting both the selective antagonism and the importance of peripheral $\mathrm{D}_{2}$-like receptors. Recently, identification of peripheral $\mathrm{D}_{2}$ receptors in the seminal vesicle of rats and humans has been established (15) and dopamine itself contracts the seminal vesicles (5), suggesting the possibility that dopamine $\mathrm{D}_{2}$ receptor localized in the seminal vesicles may modulate seminal emission in 
rats. Further investigations will be needed to elucidate this consideration.

The results of this study may provide useful information as to the treatment of patients with ejaculatory dysfunction. It is noteworthy that a prominent synergistic action was induced by the combination of a small dose of apomorphine and m-CPP without affecting the proerectile activity. Although apomorphine has been used for the treatment of sexual dysfunction, its side-effects may limit the use of higher doses and the narrowing therapeutic modality. The addition of $\mathrm{m}-\mathrm{CPP}$ or the selective $5-\mathrm{HT}_{2 \mathrm{C}}$ receptor agonist may lower the effective dose of apomorphine and provide better treatment with fewer sideeffects.

In conclusion, the results of the present study demonstrate that the combination of a small dose of apomorphine and $\mathrm{m}-\mathrm{CPP}$ results in a potentiation for inducing ejaculation and this synergistic action is likely mediated by the simultaneous activation of $\mathrm{D}_{2}$-like and 5- $\mathrm{HT}_{2 \mathrm{C}}$ receptors, respectively.

\section{Acknowledgments}

This study was supported by Grant-in Aid for Scientific Research (C) (KAKENHI 19591884) from Japan Society for the Promotion of Science.

\section{REFERENCES}

1. Bagdy G and Makara GB (1995) Paraventricular nucleus controls $5-\mathrm{HT}_{2 \mathrm{C}}$ receptor-mediated corticosterone and prolactin but not oxytocin and penile erection responses. Eur $J$ Pharmacol 275, 301-305.

2. Barone JA (1999) Domperidone: a peripherally acting dopamine $_{2}$-receptor antagonist. Ann Pharmacother 33, 429-440.

3. Berendsen HH, Jenck F and Broekkamp CL (1990) Involvement of $5-\mathrm{HT}_{1 \mathrm{C}}$-receptors in drug-induced penile erections in rats. Psychopharmacology 101, 57-61.

4. Bitran D, Thompson JT, Hull EM and Sachs BD (1989) Quinelorane (LY163502), a $\mathrm{D}_{2}$ dopamine receptor agonist, facilitates seminal emission, but inhibits penile erection in the rat. Pharmacol Biochem Behav 34, 453-458.

5. Castelli M, Rossi T, Baggio G, Bertolini A and Ferrari W (1985) Characterization of the contractile activity of dopamine on the rat isolated seminal vesicle. Pharmacol Res Commun 17, 351-359.

6. Clement P, Bernabé J, Kia HK, Alexandre L and Giuliano F (2006) $\mathrm{D}_{2}$-like receptors mediate the expulsion phase of ejaculation elicited by 8-hydroxy-2-(di-N-propylamino)tetralin in rats. $J$ Pharmacol Exp Ther 316, 830-834.

7. Coolen LM, Allard J, Truitt WA and McKenna KE (2004) Central regulation of ejaculation. Physiol Behav 83, 203-215.

8. Giuliano F, Allard J, Rampin O, Droupy S, Benoit G, Alexandre L and Bernabe J (2002) Pro-erectile effect of systemic apomorphine: existence of a spinal site of action. $J$ Urol 167, 402-406.

9. Giuliano F and Clement P (2005) Neuroanatomy and physi- ology of ejaculation. Annu Rev Sex Res 16, 190-216.

10. Giuliano F and Clement P (2006) Serotonin and premature ejaculation: from physiology to patient management. Eur Urol 50, 454-466.

11. Hoyer D, Clarke DE, Fozard JR, Hartig PR, Martin GR, Mylecharane EJ, Saxena PR and Humphrey PP (1994) International union of pharmacology classification of receptors for 5-hydroxytryptamine (Serotonin). Pharmacol Rev 46, 157203.

12. Hsieh GC, Hollingsworth PR, Martino B, Chang R, Terranova MA, O'Neill AB, Lynch JJ, Moreland RB, Donnelly-Roberts DL, Kolasa T, Mikusa JP, McVey JM, Marsh KC, Sullivan JP and Brioni JD (2004) Central mechanisms regulating penile erection in conscious rats: the dopaminergic systems related to the proerectile effect of apomorphine. J Pharmacol Exp Ther 308, 330-338.

13. Hull EM, Eaton RC, Markowski VP, Moses J, Lumley LA and Loucks JA (1992) Opposite influence of medial preoptic $D_{1}$ and $D_{2}$ receptors on genital reflexes: implications for copulation. Life Sci 51, 1705-1713.

14. Hull EM, Muschamp JW and Sato S (2004) Dopamine and serotonin: influences on male sexual behavior. Physiol Behav 83, 291-307.

15. Hyun JS, Baig MR, Yang DY, Leungwattanakij S, Kim KD, Abdel-Mageed AB, Bivalacqua TJ and Hellstrom WJ (2002) Localization of peripheral dopamine $\mathrm{D}_{1}$ and $\mathrm{D}_{2}$ receptors in rat and human seminal vesicles. J Androl 23, 114-120.

16. Kimura Y (1972) Posterior urethrogram as a method to study ejaculation. Tohoku J Exp Med 106, 89-91.

17. Kimura Y, Hatanaka K, Naitou Y, Maeno K, Shimada I, Koakutsu A, Wanibuchi F and Yamaguchi T (2004) Pharmacological profile of YM348, a novel, potent and orally active 5- $\mathrm{HT}_{2 \mathrm{C}}$ receptor agonist. Eur J Pharmacol 483, 37-43.

18. Lorrain DS, Matuszewich L and Hull EM (1998) 8-OHDPAT influences extracellular levels of serotonin and dopamine in the medial preoptic area of male rats. Brain Res $\mathbf{7 9 0}$, 217-223.

19. Marberger H (1974) Mechanisms of ejaculation. In: Physiology and Genetics of Reproduction (Coutinho E and Fuchs F, eds.), pp99-110, Plenum Press, London.

20. Mas M, Zahradnik MA, Martino V and Davidson JM (1985) Stimulation of spinal serotonergic receptors facilitates seminal emission and suppresses penile erectile reflexes. Brain Res 342, 128-134.

21. Matuszewich L, Lorrain DS, Trujillo R, Dominguez J, Putnam SK and Hull EM (1999) Partial antagonism of 8-OHDPAT's effects on male rat sexual behavior with a $\mathrm{D}_{2}$, but not a 5-HT ${ }_{1 \mathrm{~A}}$, antagonist. Brain Res 820, 55-62.

22. McKenna K (1999) Ejaculation. In: Encyclopedia of Reproduction, vol. 1 (Knobil E and Neill J, eds.), pp1002-1008, Academic Press, New York.

23. Melis MR, Argiolas A and Gessa GL (1987) Apomorphineinduced penile erection and yawning: site of action in brain. Brain Res 415, 98-104.

24. Pehek EA, Thompson JT, Eaton RC, Bazzett TJ and Hull EM (1988) Apomorphine and haloperidol, but not domperidone, affect penile reflexes in rats. Pharmacol Biochem Behav 31, 201-208.

25. Pehek EA, Thompson JT and Hull EM (1989) The effects of intracranial administration of the dopamine agonist apomorphine on penile reflexes and seminal emission in the rat. Brain Res 500, 325-332.

26. Renyi L (1985) Ejaculations induced by p-chloroamphetamine in the rat. Neuropharmacology 24, 697-704. 
27. Renyi L (1986) The effect of selective 5-hydroxytryptamine uptake inhibitors on 5-methoxy-N,N-dimethyltryptamineinduced ejaculation in the rat. Br J Pharmacol 87, 639-648.

28. Renyi L (1986) The effects of monoamine oxidase inhibitors on the ejaculatory response induced by 5 -methoxy-N,Ndimethyltryptamine in the rat. Br J Pharmacol 88, 827-835.

29. Stafford SA and Coote JH (2006) Activation of $\mathrm{D}_{2}$-like receptors induces sympathetic climactic-like responses in male and female anaesthetised rats. Br J Pharmacol 148, 510-516.

30. Stafford SA, Tang K and Coote JH (2006) Activation of lumbosacral $5-\mathrm{HT}_{2 \mathrm{C}}$ receptors induces bursts of rhythmic activity in sympathetic nerves to the vas deferens in male rats. $\mathrm{Br} J$ Pharmacol 148, 1083-1090.

31. Yonezawa A, Watanabe C, Ando R, Furuta S, Sakurada S, Yoshimura H, Iwanaga T and Kimura Y (2000) Characteriza- tion of p-chloroamphetamine-induced penile erection and ejaculation in anesthetized rats. Life Sci 67, 3031-3039.

32. Yonezawa A, Yoshizumi M, Ebiko M, Kimura Y and Sakurada S (2004) Penile erection and ejaculation induced by the serotonin releasers in male rats. J Tohoku Pharmaceutical Univ 51, 133-141.

33. Yonezawa A, Yoshizumi M, Ebiko M, Iwanaga T, Kimura $Y$ and Sakurada S (2005) Evidence for an involvement of peripheral serotonin in p-chloroamphetamine-induced ejaculation of rats. Pharmacol Biochem Behav 82, 744-750.

34. Yonezawa A, Yoshizumi M, Ebiko M, Ise SN, Watanabe C, Mizoguchi H, Kimura Y and Sakurada S (2008) Ejaculatory response induced by a $5-\mathrm{HT}_{2}$ receptor agonist $\mathrm{m}-\mathrm{CPP}$ in rats: differential roles of $5-\mathrm{HT}_{2}$ receptor subtypes. Pharmacol Biochem Behav 88, 367-373. 